\title{
Kajian Keterlambatan Proyek Engineering Procurement Construction Commissioning Jaringan Transmisi 150KV
}

\author{
Studi Kasus PLTP Karaha-Gi Garut
}

\author{
Bayu Kania \\ Fakultas Teknik \\ Program Studi Teknik Sipil \\ Universitas Langlangbuana \\ bayukania@unla.ac.id \\ Robby Gunawan Yahya \\ Fakultas Teknik \\ Program Studi Teknik Sipil \\ Universitas Langlangbuana \\ robbygunawan@unla.ac.id
}

\author{
Andri Kurniawan \\ Fakultas Teknik \\ Program Studi Teknik Sipil \\ Universitas Langlangbuana \\ kurniawan@gmail.com
}

\begin{abstract}
Abstrak - Proyek Engineering Procurement Construction Commissioning (EPCC) merupakan proyek dengan tingkat kompleksitas pekerjaan yang cukup tinggi dibandingkan dengan jenis proyek konstruksi lainnya. Kompleksitasnya yang tinggi menyebabkan proyek EPCC memiliki resiko mengalami keterlambatan yang cukup besar. Hal ini pun terjadi pada proyek EPCC Pembangunan Jaringan Transmisi 150kV PLTP Karaha-

terlambatnya pembangunan PLTP dengan bobot 0.131 ; (4) investigasi/survey awal yang tidak akurat dengan bobot 0.131; dan (5) keterlambatan pekerjaan sebelumnya dengan bobot 0.059 .

Kata kunci - keterlambatan; proyek EPCC; Engineering Procurement Construction Commissioning; jaringan transmisi; Analytic Hierarchy Process.
\end{abstract} GI Garut, yang mengalami keterlambatan selama 235 hari dari rencana pelaksanaan pekerjaan. Penelitian ini bertujuan untuk mengidentifikasi faktor-faktor penyebab keterlambatan pada proyek EPCC pembangunan jaringan transmisi. Penelitian ini dilakukan dengan metode kuantitatif dengan mengidentifikasi jenis-jenis kegiatan serta penyebabnya yang mempengaruhi keterlambatan proyek EPCC. Setelah itu jenis kegiatan serta faktor penyebab akan diukur tingkat kepengaruhannya terhadap keterlambatan proyek. Penelitian dilakukan melalui studi literatur, wawancara dengan menggunakan kuesioner kepada pihak-pihak yang terkait, serta analisis dengan Analytic Hierarchy Process (AHP) untuk mengetahui bobot masing-masing parameter. Dari sembilan belas jenis pekerjaan, terdapat lima item pekerjaan yang paling berpengaruh dalam menyebabkan terjadinya keterlambatan proyek EPCC Pembangunan Jaringan Transmisi 150kV PLTP KarahaGI Garut, yaitu: (1) pekerjaan re-route survey; (2) pekerjaan pondasi; (3) pekerjaan erection tower; (4) pemasangan \& pengukuran tahanan tower grounding; dan (5) pekerjaan stringing. Adapun lima faktor penyebab keterlambatan yang paling berpengaruh terhadap keterlambatan adalah: (1) perubahan/ penambahan jumlah tower dengan bobot 0.177 ; (2) kurangnya sumber daya manusia dengan bobot 0.148 ; (3)

\section{Pendahuluan}

Proyek EPCC (Engineering Procurement Construction Commissioning) Jaringan Transmisi $150 \mathrm{kV}$ PLTP Karaha-GI (Gardu Induk) Garut adalah proyek konstruksi tower transmisi SUTT (Saluran Udara Tegangan Tinggi) $150 \mathrm{kV}$ yang membentang sepanjang 24,85 km yang melewati Kabupaten Tasikmalaya dan Kabupaten Garut.

Sesuai pasal 3 dalam dokumen kontrak perjanjian pengadaan jasa EPCC Jaringan Transmisi $150 \mathrm{kV}$ PLTP Karaha-Gardu Induk Garut (Cilawu), jangka waktu perjanjian adalah tanggal 1 November 2014 sampai dengan 31 Januari 2018 dengan jangka waktu pelaksanaan pekerjaan 16 bulan. Akan tetapi seiring berjalannya waktu terdapat kendala yang mengakibatkan bertambahnya waktu pekerjaan yang dituangkan dalam addendum IV yang isinya memperpanjang waktu perjanjian terhitung mulai 1 November 2014 sampai 30 September 2018 dengan jangka waktu pelaksanaan pekerjaan menjadi 24 bulan.

\section{Metode}

\subsection{Metode Survei}

Dalam penelitian ini dilakukan survei pengumpulan data, yang meliputi : 
1. Studi kepustakaan, yaitu pengambilan data dengan cara mempelajari literatur-litertaur, buku-buku, dan dokumen lainnya yang berhubungan dengan pokokpokok penelitian. Studi kepustakaan ini bertujuan untuk menjaring data sekunder sebagai bahan referensi dalam membantu melakukan analisis terhadap permasalahan yang ada dilapangan.

2. Studi Lapangan, yaitu teknik pengambilan data dengan melakukan pengamatan langsung pada objek penelitian. Studi lapangan ini menggunakan dua bentuk kegiatan yaitu :

a. Observasi, yaitu pengambilan data atau informasi dengan mengamati langsung terhadap objek yang sedang diteliti untuk mengetahui kondisi yang sebenarnya.

b. Angket, yaitu teknik pengumpulan data yang dilakukan dengan cara menyebarkan daftar pertanyaan tertulis dan terstruktur kepada responden untuk memperoleh keterangan mengenai masalah yang diteliti. Jenis angket yang digunakan adalah angket yang berisi pernyataan-pernyataan dengan disertai alternatif jawaban yang telah disediakan.

\subsection{Analisis Data}

Tahap pertama di dalam penelitian ini adalah melakukan identifikasi atau diagnosa awal untuk mencari pekerjaan yang mengalami penurunan prestasi atau keterlambatan progres berdasarkan data dari kurva S. Kurva S digunakan sebagai dasar analisa dan identifikasi pada jenis pekerjaan yang mengalami keterlambatan progress dan juga untuk menentukan waktu pelaksanaan pekerjaan yang terlambat pada proyek tersebut serta mendapatkan seberapa besar penurunan yang terjadi pada progress komulatif rencana dengan progress komulatif realisasi. Tahapan analisis ini di antaranya:

1. Analisis pekerjaan yang mengalami keterlambatan;

2. Menentukan deviasi progress yang mengalami keterlambatan;

3. Identifikasi penyebab keterlambatan progress;

4. Mengkaji penyebab keterlambatan proyek;

5. Mendapatkan pekerjaan yang paling berpengaruh terhadap keterlambatan.

\subsection{Analisis Statistik}

Analisis statistik yang dilakukan meliputi :

1. Menentukan skor terhadap pernyataan dalam kuesioner

Setelah pernyataan-pernyataan ditentukan, maka langkah selanjutnya adalah menentukan skor untuk pernyataan-pernyataan tersebut. Skala pengukuran data memiliki skala ordinal yang menunjukkan perbedaan tingkatan subyek secara kuantitatif. Persepsi responden diurut menjadi: Tidak berpengaruh, agak berpengaruh, berpengaruh dan sangat berpengaruh. Kemudian data kuantitatif tersebut dirubah menjadi data kuantitatif sebagai berikut: Tidak berpengaruh diberi nilai 0 , agak berpengaruh diberi nilai 1 , berpengaruh diberi nilai 2, sangat berpengaruh diberi nilai 3 .

2. Menentukan ranking permasalahan penyebab terjadinya keterlambatan proyek

Ranking secara umum pada jawaban responden dianalisis berdasarkan nilai rata-rata persepsi. Dari hasil nilai akan dihasilkan peringkat dari masing-masing faktor penyebab keterlambatan proyek pembangunan EPCC Jaringan Transmisi $150 \mathrm{kV}$ PLTP Karaha-GI Garut tersebut sehingga dapat diketahui faktor utamanya. Selanjutnya setelah diketahui faktor utama dari penyebab keterlambatan tersebut, maka dijabarkan lagi ke dalam subfaktor dan kemudian ditentukan peringkat atau ranking dengan menggunakan rumus yang sama. Faktor penilaian pada harga rata-rata dibuat batasan sebagai berikut : harga rata -rata kurang dari 0,5 dianggap tidak berpengaruh, $0,5 \quad \mathrm{~s} / \mathrm{d} \quad 1,5$ dianggap agak berpengaruh, lebih besar 1,5 s/d 2,5 dianggap berpengaruh lebih besar 2,5 s/d 3,0 dianggap sangat berpengaruh.

3. Analytic Hierarchy Process (AHP)

Analisis proses hirarki dilakukan untuk mengetahui bobot dari masing-masing faktorfaktor penyebab terjadinya keterlambatan.

\section{Hasil dan Diskusi}

\subsection{Jenis Pekerjaan Proyek Jaringan Transmisi $150 \mathrm{kV}$ PLTP Karaha - GI Garut yang Mengalami Keterlambatan}

Berdasarkan hasil analisis terhadap data kurva S, diperoleh 16 (enam belas) jenis pekerjaan pada proyek jaringan transmisi yang mengalami keterlambatan. Jenis pekerjaan serta rangking seperti yang terlihat pada Tabel 1.

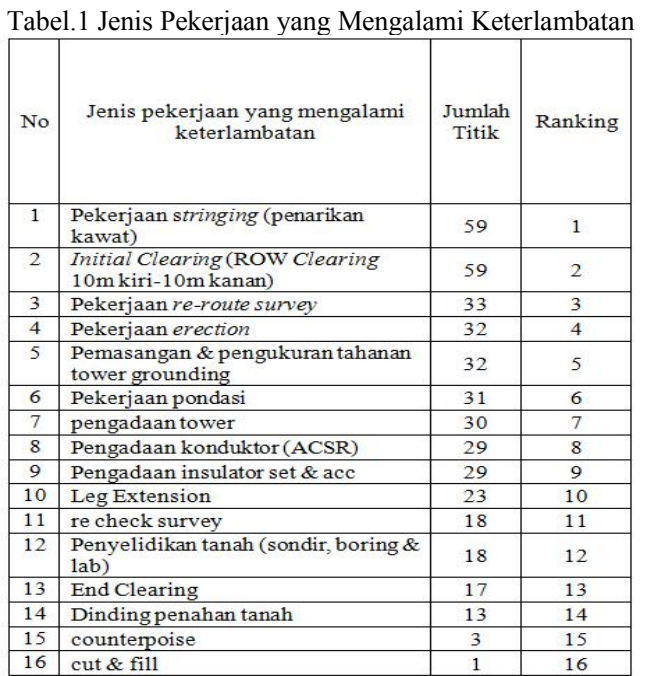




\subsection{Faktor-Faktor Penyebab Keterlambatan pada Proyek EPCC Jaringan Transmisi 150kV PLTP Karaha - GI Garut}

Faktor-faktor penyebab keterlambatan proyek berdasarkan jenis pekerjaan selengkapnya seperti yang disebutkan pada Tabel. 2 .

Dari Tabel 2, diketahui bahwa faktor-fator yang menyebabkan keterlambatan dapat terjadi pada beberapa jenis pekerjaan, sehingga jika dikelompokkan berdasarkan tipe keterlambatan (excusable delay, non-excusable delay, dan compensable delay) terdapat 25 (dua puluh lima) faktor yang menyebabkan keterlambatan dalam prooyek EPCC Jaringan Transmisi $150 \mathrm{kV}$ PLTP Karaha - GI Garut, seperti yang dijelaskan pada Tabel 3.

\subsection{Uji Validitas dan Perangkingan Permasalahan}

Nilai indeks validitas pada masing-masing item pertanyaan yang diukur melalui nilai korelasi product moment yang memiliki nilai di atas nilai koefisien valid sebesar 0.344 , terdapat 8 (delapan) item mempunyai nilai lebih kecil disbanding $r$ tabel dan dinyatakan tidak valid untuk diikutsertakan pada proses penelitian selanjutnya sedangkan 17 (tujuh belas) item dinyatakan valid dan bisa dilanjutkan pada proses analisis selanjutnya.

Tabel.2 Faktor-faktor Penyebab Keterlambatan Proyek berdasarkan Jenis

\begin{tabular}{|c|c|c|}
\hline \multicolumn{3}{|c|}{ Pekerjaan } \\
\hline $\mathrm{No}$ & Katopon & 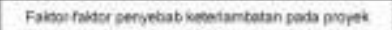 \\
\hline 1 & 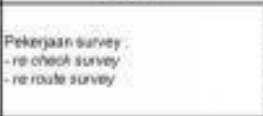 & 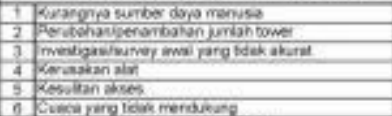 \\
\hline 2 & 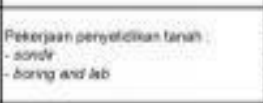 & 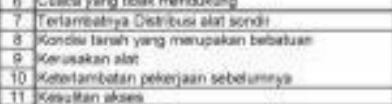 \\
\hline 3 & Peteplan pergation tiue & 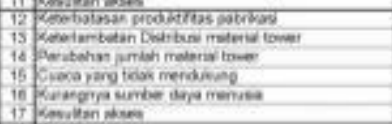 \\
\hline 4 & 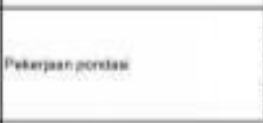 & 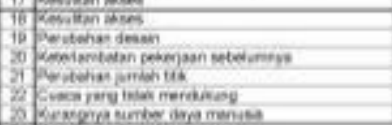 \\
\hline n & 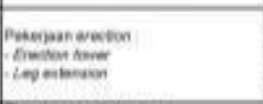 & 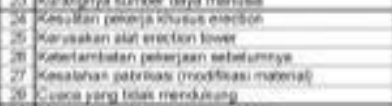 \\
\hline त & 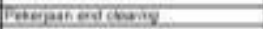 & 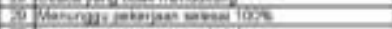 \\
\hline 7 & Beterpan perostam ES & 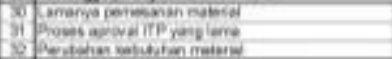 \\
\hline s & 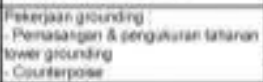 & 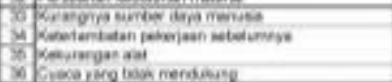 \\
\hline 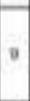 & Pesepase abvory & 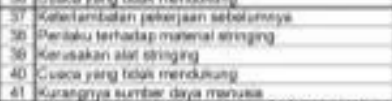 \\
\hline 10 & Prompan sot A A & 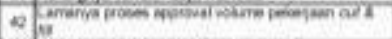 \\
\hline 11 & Peterasn qndrop pensan larah & 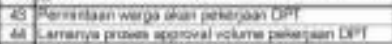 \\
\hline 12 & 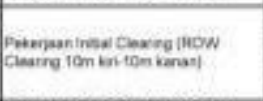 & 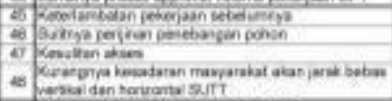 \\
\hline 13 & 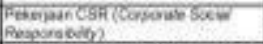 & 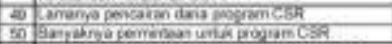 \\
\hline 14 & 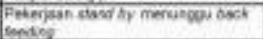 & 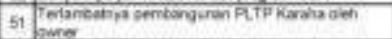 \\
\hline 15 & Fats Limain & 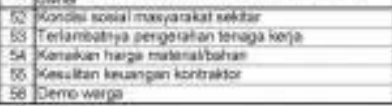 \\
\hline
\end{tabular}

Tabel.3 Faktor-faktor Penyebab Keterlambatan Proyek berdasarkan Tipe Keterlambatan

\begin{tabular}{|c|c|c|}
\hline Tpe Keteriambutan & Varatio & Jemis Masalah. \\
\hline \multirow{6}{*}{ Eucurable delay } & $\begin{array}{l}P 1 \\
P 2\end{array}$ & 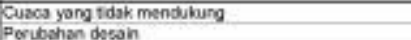 \\
\hline & P3 & Campur targan warga \\
\hline & P4 & Sultrya peri inan borthadap warga \\
\hline & P5 & Kurangnyo kesadaran wayo aksn aturan suTT \\
\hline & P5 & Kondei scoid masyaizkat sektat \\
\hline & P7 & Kenakan herga muborialbahen \\
\hline \multirow{14}{*}{ NonErcusatle dolay } & $\mathrm{PB}$ & Kurangrya sumbar daya manusa \\
\hline & P9 & Kerwabahn aibl \\
\hline & P10 & Kesultarn ataes \\
\hline & P11 & 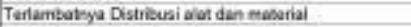 \\
\hline & $\mathrm{P} 12$ & Kendsi arah yang merupakan bebesuan \\
\hline & P13 & 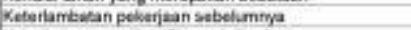 \\
\hline & P14 & Ketarthatesan prod_chiftus pebrikas \\
\hline & P15 & Kesablahtan pabrikas \\
\hline & P16 & 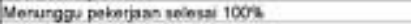 \\
\hline & P17 & Lamanya permesaran materal \\
\hline & P18 & Periahu sothadap material \\
\hline & P18 & Lamanyas pencairan dons program CSR \\
\hline & $P 20$ & Terlambatrya pengenthen tenega karis? \\
\hline & P21 & Xesulton bevange bortrokter \\
\hline \multirow{4}{*}{ Camponasite detsy } & $P 22$ & 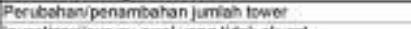 \\
\hline & P23 & 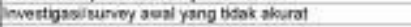 \\
\hline & P24 & Lamanys proses acprovis dokumen. \\
\hline & P25 & Tertambatrya pembeng anen FL TP Kavahs oleh owner \\
\hline
\end{tabular}

Tabel.4 Hasil Uji Validitas

\begin{tabular}{|c|c|c|c|c|}
\hline Woivele & Jask Mastiah & rtheng & ITatow I & Ketinglat \\
\hline P & 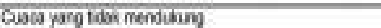 & 0 का & 63at & พัต \\
\hline 82 & 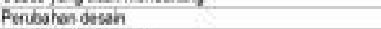 & 0 क्ष & 0344 & wald \\
\hline p9 & Comput bongen wiage & .0004 & 0344 & not wad \\
\hline $\mathrm{Pa}$ & 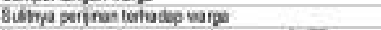 & 0809 & 0344 & not wed \\
\hline Ps & 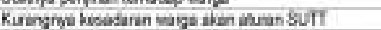 & 0.205 & 0344 & nat wide \\
\hline iv & Kondai acsoi maspakat naktat & 0.515 & 0344 & nat vald \\
\hline $\bar{p}$ & Kenaban hava materdibaton & 0.35 & 0.344 & vald \\
\hline 两 & Kunangrya umbar dop ruring & प.5ा & 0344 & vald \\
\hline $\mathrm{Pa}$ & Kenrevian alat & 04 & 0344 & vald \\
\hline P10 & Keulatanakines & 000 & $03 \mathbf{M}$ & waid \\
\hline PI & 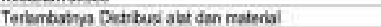 & QAn & 0.34 & wald \\
\hline P12. & 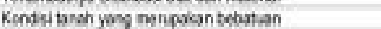 & 018 & 0.344 & not waid \\
\hline Pis & Keterbregtan peborion setekninga & $0<42$ & 0344 & wibs \\
\hline Pi4 & 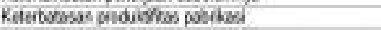 & 0.3 & 0.344 & Whin \\
\hline P16 & Keselater patrivasi & 082 & 0344 & waid \\
\hline P16 & Henvepu pekspan selosai $10 \mathrm{~s}$ & 0,121 & 0344 & not wowed \\
\hline Pil & Lomaryp pertwasten miderial & 0.522 & 0344 & not verd \\
\hline लि & Portiaku fattodap matorel & OSts & 0344 & vald \\
\hline P12 & Lamaya pencaran dare program CSR & 0.297 & 0344 & nst voded \\
\hline$P \infty 0$ & 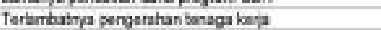 & 0.30 & 0344 & vald \\
\hline P2i & Keaultan kewaygen knontraits & 0.573 & 0.344 & valli \\
\hline קय & 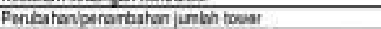 & परके & 034 & wald \\
\hline P23 & 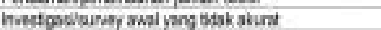 & 000 & $0 \mathbf{M i}$ & waild \\
\hline$P 24$ & Lanany srees sporowid dohimen & $0 \times 0$ & 0344 & whild \\
\hline Pr. & 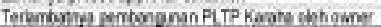 & nan? & 0.944 & wivi \\
\hline
\end{tabular}

Berdasarkan hasil pengumpulan data melalui penyebaran kuesioner yang dibagikan kepada 35 responden diperoleh hasil penerltian berkaitan dengan tanggapan responden terhadap faktor penyebab keterlambatan penyelesaian proyek yang disajikan dalam Tabel 5 sebagai berikut.

Tabel.5 Tanggapan Responden

\begin{tabular}{|c|c|c|c|c|c|c|c|}
\hline \multirow{3}{*}{ Variabh } & \multirow{3}{*}{ doris Kassitah } & \multicolumn{5}{|c|}{ Rihan dawoban } & \multirow{3}{*}{ Jimtah } \\
\hline & & 5 & 4 & 3 & 2 & 1 & \\
\hline & & 88 & 8 & $\mathrm{CS}$ & T8: & 878 & \\
\hline$P \mid$ & Cuaca yaeg tisk mensiking & 1 & 14 & 17 & 3 & 0 & 35 \\
\hline F & Ponbahan desain & 5 & 15 & II & 4 & 0 & 3 \\
\hline [P] & Keno kan harga mebrialthatan & 0 & A & 21 & 7 & 3 & $x$ \\
\hline Fi & 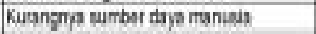 & 7 & 18 & 11 & 1 & 0 & $x$ \\
\hline 19 & Kensakan alat & 0 & 14 & 15 & $B$ & 0 & 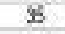 \\
\hline P10 & Keaultan abes: & 5 & 14 & 15 & 1 & 0 & 35 \\
\hline P11 & Tediambenyo Dostieus alat dan monial & 2 & 17 & 14 & 2 & 0 & 35 \\
\hline P13 & 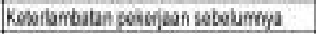 & 6 & 13 & 14 & 2 & 0 & 35 \\
\hline $\mathrm{P} 14$ & Kovortabasan posdibthicas patrikasi & 1 & 12 & 15 & 5 & 2 & 35 \\
\hline P15 & Kosishan pacikas & 2 & 22 & 8 & 2 & 0 & 35 \\
\hline p18 & Portsku tortasap maiarial & 0 & 8 & 2 & 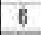 & 0 & 3 \\
\hline P20 & 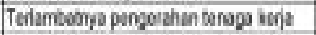 & 1 & 16 & 16 & 1 & 1 & 35 \\
\hline P21 & Kesidtan keuangan bontroktor & 0 & 11 & 15 & 6 & 3 & 35 \\
\hline$P 22$ & Pentoshan semontostan jumbah tower & II & 15 & 9 & 0 & 0 & $x$ \\
\hline$P 23$ & 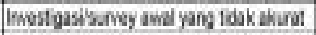 & 3 & 19 & 13 & 0 & 0 & 35 \\
\hline$P 24$ & Lameryo croses acprowal dowimen & 2 & 17 & 16 & 0 & 0 & 35 \\
\hline P25 & 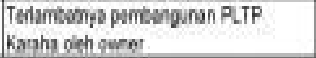 & 3 & 10 & 13 & 1 & 0 & 35 \\
\hline
\end{tabular}

Hasil akhir diperoleh rangking penyebab keterlambatan yang disampaikan pada Tabel 6 . 
Tabel.6 Rangking Penyebab Keterlambatan

\begin{tabular}{|c|c|c|c|}
\hline Var & Jenis Masalah & Mean & Rangking \\
\hline P1 & Cuaca yang tidak mendukung & 3.37 & 12 \\
\hline $\mathrm{P} 2$ & Perubahan desain & 3.60 & 8 \\
\hline P7 & Kenaikan harga material/bahan & 2.74 & 17 \\
\hline P8 & $\begin{array}{l}\text { Kurangnxa sumber daxa } \\
\text { manusia }\end{array}$ & 3.83 & 2 \\
\hline P9 & Kerusakan alat & 3.23 & 13 \\
\hline $\mathrm{P} 10$ & Kesulitan akses & 3.66 & 5 \\
\hline P11 & $\begin{array}{l}\text { Terlambatnya Distribusi alat } \\
\text { dan material }\end{array}$ & 3.54 & 10 \\
\hline P13 & $\begin{array}{l}\text { Keterlambatan pekerjaan } \\
\text { sebelumnxa }\end{array}$ & 3.66 & 5 \\
\hline P14 & $\begin{array}{l}\text { Keterbatasan produktifitas } \\
\text { pabrikasi. }\end{array}$ & 3.14 & 14 \\
\hline P15 & Kesalahan pabrikasi & 3.69 & 4 \\
\hline P18 & Perilaku terhadap material & 3.00 & 15 \\
\hline $\mathrm{P} 20$ & $\begin{array}{l}\text { Terlambatnva pengerahan } \\
\text { tenaga kerja }\end{array}$ & 3.43 & 11 \\
\hline $\mathrm{P} 21$ & Kesulitan keuangan kontraktor & 2.97 & 16 \\
\hline $\mathrm{P} 22$ & $\begin{array}{l}\text { Perubahan/penambahan jumlah } \\
\text { tower }\end{array}$ & 4.06 & 1 \\
\hline P23 & $\begin{array}{l}\text { Investigasi/survey awal yang } \\
\text { tidak akurat. }\end{array}$ & 3.71 & 3 \\
\hline P24 & $\begin{array}{l}\text { Lamanya proses approval } \\
\text { dokumen }\end{array}$ & 3.60 & 8 \\
\hline P25 & $\begin{array}{l}\text { Terlambatnya pembangunan } \\
\text { PLTP Karaha oleh owner }\end{array}$ & 3.66 & 5 \\
\hline
\end{tabular}

\subsection{Pembobotan Faktor Permasalahan dengan AHP}

\subsubsection{Variabel}

Variabel AHP terdiri dari 17 variabel yang merupakan jenis permasalahan final (Tabel 6) seperti yang disampaikan pada Tabel 7 berikut ini:

\begin{tabular}{|c|c|c|}
\hline \multicolumn{3}{|c|}{ Tabel.7 Variabel AHP } \\
\hline Tipe Keterlambatan & Variable & $\begin{array}{c}\text { Jenis Masalah } \\
\end{array}$ \\
\hline Compensable delay & F1 & Perubahan/penambahan jumlah tower \\
\hline Non-Excusable delay & $\mathrm{F} 2$ & Kurangnya sumber daya manusia \\
\hline Compensable delay & F3 & Investigasi/survey awal yang tidak akurat \\
\hline Non-Excusable delay & F4 & Kesalahan pabrikasi \\
\hline Non-Excusable delay & F5 & Kesulitan akses \\
\hline Non-Excusable delay & F6 & Keterlambatan pekerjaan sebelumnya \\
\hline Compensable delay & F7 & $\begin{array}{l}\text { Terlambatnya pembangunan PLTP Karaha oleh } \\
\text { owner }\end{array}$ \\
\hline Excusable delay & F8 & Perubahan desain \\
\hline Compensable delay & F9 & Lamanya proses approval dokumen \\
\hline Non-Excusable delay & F10 & Terlambatnya Distribusi alat dan material \\
\hline Non-Excusable delay & F11 & Terlambatnya pengerahan tenaga kerja \\
\hline Excusable delay & F12 & Cuaca yang tidak mendukung \\
\hline Non-Excusable delay & F13 & Kerusakan alat \\
\hline Non-Excusable delay & F14 & Keterbatasan produktifitas pabrikasi \\
\hline Non-Excusable delay & F15 & Perilaku terhadap material \\
\hline Non-Excusable delay & F16 & Kesulitan keuangan kontraktor \\
\hline Excusable delay & F17 & Kenaikan harga material bahan \\
\hline
\end{tabular}

\subsubsection{Responden}

Karakteristik responden untuk kuesioner kedua diambil berdasarkan peranannya terhadap proyek EPCC Jaringan Transmisi 150kV PLTP Karaha-GI Garut. Untuk menentukan apakah responden dapat dianggap expert dapat dilihat dari jabatan dan pengalaman kerja yang didapatkan.
Tabel.8 Data Jumlah Responden untuk Pembobotan Permasalahan

\begin{tabular}{|c|c|c|c|}
\hline Responden & $\begin{array}{c}\text { Jumbla } \\
\text { kuesioner } \\
\text { yang } \\
\text { dibagikan }\end{array}$ & $\begin{array}{c}\text { Jumlah } \\
\text { kuesioner } \\
\text { yang terisi }\end{array}$ & $\begin{array}{c}\text { Pengalaman } \\
\text { (Tahun) }\end{array}$ \\
\hline $\begin{array}{c}\text { Manajer } \\
\text { Proxek }\end{array}$ & 1 & 1 & $>10$ \\
\hline $\begin{array}{c}\text { General } \\
\text { Manager }\end{array}$ & 1 & 1 & $5-10$ \\
\hline $\begin{array}{c}\text { Kegrdinator } \\
\text { PM }\end{array}$ & 1 & 1 & $5-10$ \\
\hline Total & 3 & 3 & \\
\hline
\end{tabular}

\subsubsection{Pembobotan dengan AHP}

Dalam AHP diawali dengan menentukan tingkat kepentingan antar kriteria (Tabel 9), lalu selanjutnya diperoleh matriks perbandingan berpasangan (Tabel 10) dan akhirnya diperoleh bobot kriteria setiap perbandingan (Tabel 11).

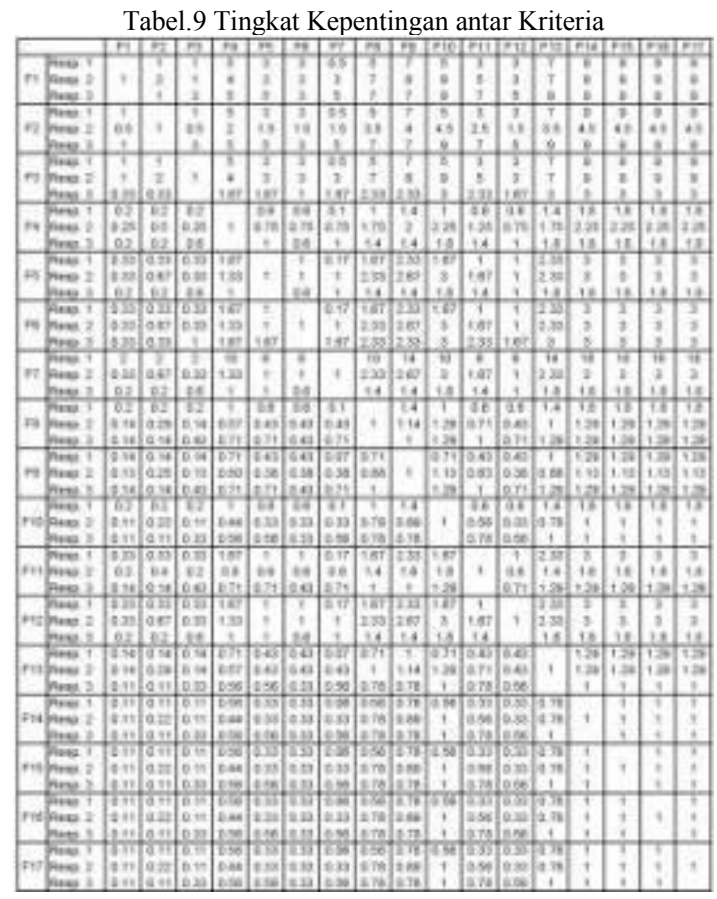

Tabel.10 Matriks Perbandingan Berpasangan

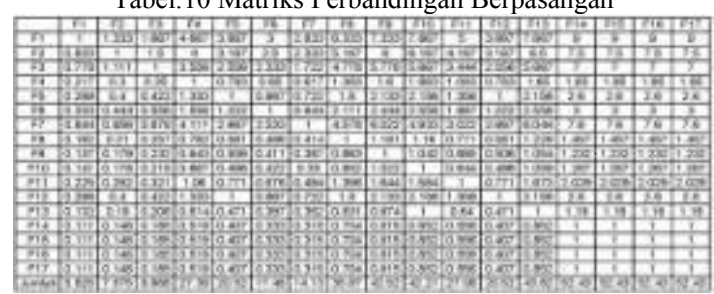

Tabel.11 Bobot kriteria setiap perbandingan

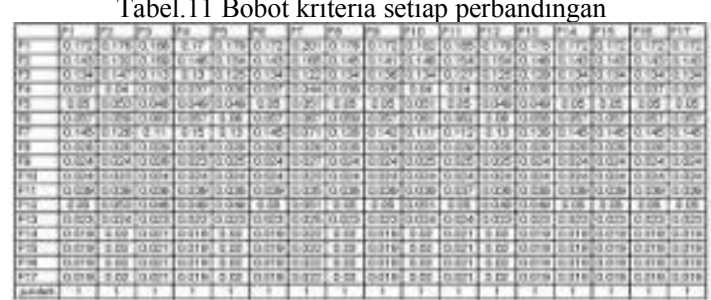

Bobot setiap variabel digambarkan dalam bentuk hirarki seperti pada Gambar 1. 


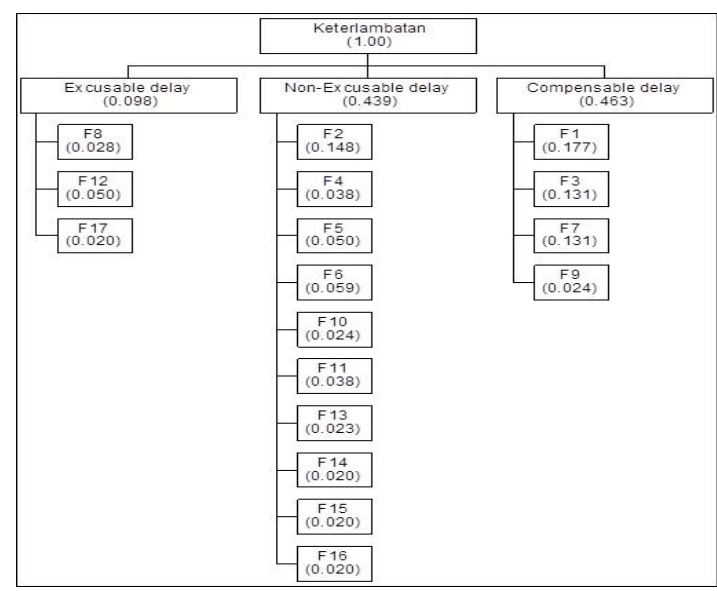

Gambar.1 Hasil pembobotan dalam bentuk pohon hirarki

\subsubsection{Peringkat Faktor Permasalahan}

Peringkat faktor permasalahan berdasarkan hasil bobot seperti yang dapat dilihat pada Tabel 12 .

Tabel.12 Pembobotan Faktor Permasalahan

\begin{tabular}{|c|c|c|c|}
\hline $\begin{array}{c}\text { Jenis } \\
\text { keterlambatan }\end{array}$ & Faktor-faktor keterlambatan & Bobot & Peringkat \\
\hline $\begin{array}{l}\text { Compensable } \\
\text { delay }\end{array}$ & $\begin{array}{l}\text { Perubahan/penambahan } \\
\text { jumlah tower }\end{array}$ & 0.1773 & 1 \\
\hline $\begin{array}{l}\text { Non-Excusable } \\
\text { delay }\end{array}$ & $\begin{array}{l}\text { Kurangnya sumber daya } \\
\text { manusia }\end{array}$ & 0.1479 & 2 \\
\hline $\begin{array}{l}\text { Compensable } \\
\text { delay }\end{array}$ & $\begin{array}{l}\text { Terlambatnya pembangunan } \\
\text { PLTP Karaha oleh owner }\end{array}$ & 0.1308 & 3 \\
\hline $\begin{array}{l}\text { Compensable } \\
\text { delay }\end{array}$ & $\begin{array}{l}\text { Investigasi/survey awal yang } \\
\text { tidak akurat }\end{array}$ & 0.1307 & 4 \\
\hline $\begin{array}{l}\text { Non-Excusable } \\
\text { delay }\end{array}$ & $\begin{array}{l}\text { Keterlambatan pekerjaan } \\
\text { sebelumnya }\end{array}$ & 0.0591 & 5 \\
\hline $\begin{array}{l}\text { Non-Excusable } \\
\text { delay }\end{array}$ & Kesulitan akses & 0.0498 & 6 \\
\hline Excusable delay & Cuaca yang tidak mendukung & 0.0498 & 6 \\
\hline $\begin{array}{l}\text { Non-Excusable } \\
\text { delay }\end{array}$ & Kesalahan pabrikasi & 0.0384 & 8 \\
\hline $\begin{array}{l}\text { Non-Excusable } \\
\text { delay }\end{array}$ & $\begin{array}{l}\text { Terlambatnya pengerahan } \\
\text { tenaga kerja }\end{array}$ & 0.0379 & 9 \\
\hline Excusable delay & Perubahan desain & 0.0281 & 10 \\
\hline $\begin{array}{l}\text { Compensable } \\
\text { delay }\end{array}$ & $\begin{array}{l}\text { Lamanya proses approval } \\
\text { dokumen }\end{array}$ & 0.0243 & 11 \\
\hline $\begin{array}{l}\text { Non-Excusable } \\
\text { delay }\end{array}$ & $\begin{array}{l}\text { Terlambatnya Distribusi alat } \\
\text { dan material }\end{array}$ & 0.0240 & 12 \\
\hline $\begin{array}{l}\text { Non-Excusable } \\
\text { delay }\end{array}$ & Kerusakan alat & 0.0231 & 13 \\
\hline $\begin{array}{l}\text { Non-Excusable } \\
\text { delay }\end{array}$ & $\begin{array}{l}\text { Keterbatasan produktifitas } \\
\text { pabrikasi }\end{array}$ & 0.0197 & 14 \\
\hline $\begin{array}{l}\text { Non-Excusable } \\
\text { delay }\end{array}$ & Perilaku terhadap material & 0.0197 & 14 \\
\hline $\begin{array}{l}\text { Non-Excusable } \\
\text { delay }\end{array}$ & Kesulitan keuangan kontraktor & 0.0197 & 14 \\
\hline Excusable delay & $\begin{array}{l}\text { Kenaikan harga } \\
\text { material bahan }\end{array}$ & 0.0197 & 14 \\
\hline
\end{tabular}

\subsubsection{Pembobotan Faktor Permasalahan}

Pembobotan faktor permasalahan untuk tipe keterlambatan dan jenis permasalahan selengkapnya dapat dilihat pada Tabel 13 .

\begin{tabular}{|c|c|c|}
\hline No. & $\begin{array}{l}\text { Tipe } \\
\text { Keterlambat } \\
\text { an }\end{array}$ & Jenis Permasalahan \\
\hline 1. & $\begin{array}{l}\text { Compensabl } \\
\text { e delay } \\
(0,463)\end{array}$ & $\begin{array}{l}\text { a. Perubahan/penambahan jumlah } \\
\text { tower }(0.177) \\
\text { b. Terlambatnya pembangunan PLTP } \\
\text { Karaha oleh owner }(0.131) \\
\text { c. Investigasi/survey awal yang tidak } \\
\text { akurat }(0.131) \\
\text { d. Lamanya proses approval dokumen } \\
(0.024)\end{array}$ \\
\hline 2. & $\begin{array}{l}\text { Non- } \\
\text { excusable } \\
\text { delay } \\
(0.439)\end{array}$ & $\begin{array}{l}\text { a. Kurangnya sumber daya manusia } \\
(0.148) \\
\text { b. Keterlambatan pekerjaan } \\
\text { sebelumnya }(0.059) \\
\text { c. Kesulitan akses }(0.05) \\
\text { d. Kesalahan pabrikasi }(0.038) \\
\text { e. Terlambatnya pengerahan tenaga } \\
\text { kerja }(0.038) \text {. } \\
\text { f. Terlambatnya Distribusi alat dan } \\
\text { material }(0.024) \\
\text { g. Kerusakan alat }(0.023) \\
\text { h. Keterbatasan produktifitas pabrikasi } \\
\text { (0.0197) } \\
\text { i. Perilaku terhadap material ( } 0.0197) \\
\text { j. Kesulitan keuangan kontraktor } \\
\end{array}$ \\
\hline 3. & $\begin{array}{l}\text { Excusable } \\
\text { delay } \\
(0.098)\end{array}$ & $\begin{array}{l}\text { a. Cuaca yang tidak mendukung }(0.05) \\
\text { b. Perubahan desain }(0.028) \\
\text { c. Kenaikan harga material/bahan } \\
(0.0197)\end{array}$ \\
\hline
\end{tabular}

\section{Kesimpulan}

1. Dari 19 (sembilan belas) jenis pekerjaan dalam proyek jaringan transmisi $150 \mathrm{kv}$ PLTP Karaha-GI Garut yang mengalami keterlambatan, terdapat 5 (lima) jenis pekerjaan yang paling berpengaruh terhadap keterlambatan pekerjaan, yaitu : (1) pekerjaan re-route survey; (2) pekerjaan pondasi; (3) pekerjaan erection tower; (4) pemasangan \& pengukuran tahanan tower grounding; dan (5) pekerjaan stringing.

2. Dari 25 (dua puluh lima) faktor keterlambatan dalam proyek ini, terdapat 5 (lima) faktor utama yang paling mempengaruhi keterlambatan proyek, yaitu: (1) perubahan/penambahan jumlah tower; (2) kurangnya sumber daya manusia; (3) terlambatnya pembangunan PLTP Karaha ; (4) investigasi/survey awal yang tidak akurat; dan (5) keterlambatan pekerjaan sebelumnya.

\section{Ucapan Terimakasih}

Terima kasih yang sebesar-besarnya kami ucapkan kepada kontraktor proyek transmisi yang telah membantu dalam pelaksanaan penelitian ini. 


\section{Daftar Pustaka}

[1] Ariful Bakhtiar, Soehardjono Agoes dan Hasyim M. Hamzah. Analisis Faktor-Faktor Yang Mempengaruhi Keterlambatan Proyek Konstruksi. Jurnal Rekayasa Sipil / volume 6, No.1 (2012)

[2] Handayani, R., Frederika, A., \& Wiranata, A. Analisis Faktor-Faktor Penyebab Keterlambatan Pelaksanaan Pekerjaan Proyek Gedung Di Kabupaten Jembrana. Jurnal Ilmiah Elektronik Insfrastruktur Teknik Sipil, Volume 2, N0.1, Pebruari (2013).

[3] Hutasoit P. Hubertus, Sompie B. F. Pratasis Pingkan A. K. Analisis Durasi Terhadap Peningkatan Biaya Pada Konstruksi. Jurnal Teknik Sipil, Vol. 12, N0.61,Desember (2013).

[4] Suyatno, 2010. Analisis Faktor Penyebab Keterlambatan Penyelesaian Proyek Gedung Aplikasi Model Regresi. Tesis Magister Teknik Sipil Universitas Diponegoro (2010).

[5] Widiasanti, dan Lenggogeni. Manajemen Konstruksi. Bandung: PT Remaja Rosdakarya (2013).

[6] Alonso A Jose dan Lamata M Teresa. "Consistency The Analytic Hierarchy Process: A New Approach". International Journal of Uncertainty, World Scientific Publishing Company (2006).

[7] Anonimus, 2002. Ruang bebas dan jarak bebas minimum pada Saluran Udara Tegangan Tinggi (SUTT) dan Saluran Udara Tegangan Ekstra Tinggi (SUTET) (SNI 04-69182002). Badan Standarisasi Nasional

[8] Anonimus, 2010. Kriteria Desain Tower Rangka Baja (Latticed Steel Tower) Untuk Saluran Udara Tegangan Tinggi dan Tegangan Ekstra Tinggi (SPLN T5.004:2010). PT. PLN (Persero) 